J. Dairy Sci. 95:5109-5114

http://dx.doi.org/10.3168/jds.2012-5650

(C) American Dairy Science Association ${ }^{\circledR}, 2012$.

\title{
Hot topic: Apparent total-tract nutrient digestibilities measured commercially using 120-hour in vitro indigestible neutral detergent fiber as a marker are related to commercial dairy cattle performance
}

\author{
A. Schalla, ${ }^{*}$ L. Meyer,† Z. Meyer, † S. Onetti, ${ }^{*}$ A. Schultz, ${ }^{*}$ and J. Goeser ${ }^{* 1}$ \\ *Vita Plus Corp., Madison, WI 53725 \\ †Rock River Laboratory, Watertown, WI 53094
}

\begin{abstract}
Measuring individual feed nutrient concentration is common practice for field dairy nutritionists. However, accurately measuring nutrient digestibility and using digestion values in total digestible nutrients models is more challenging. Our objective was to determine if in vivo apparent total-tract nutrient digestibility measured with a practical approach was related to commercial milk production parameters. Total mixed ration and fecal samples were collected from highproducing cows in pens on 39 commercial dairies and analyzed at a commercial feed and forage testing laboratory for nutrient concentration and $120-\mathrm{h}$ indigestible NDF (iNDF) content using the Combs-Goeser in vitro digestion technique. The 120-h iNDF was used as an internal marker to calculate in vivo apparent nutrient digestibilities. Two samples were taken from each dairy and were separated in time by at least 3 wk. Samples were targeted to be taken within $7 \mathrm{~d}$ of Dairy Herd Improvement (DHI) herd testing. Approved DHI testers measured individual cow milk weights as well as fat and protein concentrations. Individual cow records were averaged by pen corresponding to the total mixed ration and fecal samples. Formulated diet and dry matter intake (DMI) records for each respective pen were also collected. Mixed model regression analysis with dairy specified as a random effect was used to relate explanatory variables (diet nutrient concentrations, formulated DMI, in vivo apparent nutrient digestibilities, and fecal nutrient concentrations) to milk production measures. Dry matter intake, organic matter (OM) digestibility, fecal crude protein $(\mathrm{CP})$ concentration, and fecal ether extract concentration were related to milk, energy-corrected milk, and fat yields. Milk protein concentration was related to $\mathrm{CP}$ digestibility, and milk protein yield was related to DMI, OM digestibility, CP digestibility, and ether extract digestibility. Although many studies
\end{abstract}

Received April 20, 2012.

Accepted June 13, 2012.

${ }^{1}$ Corresponding author: jgoeser@vitaplus.com have related DMI and OM digestibility to milk production under controlled experimental settings, very few have related practical in vivo measures to milk production. By documenting the practical OM digestibility relationship with milk production, nutritionists and scientists may have confidence in this approach for measuring diet performance and collecting nutritional data for commercial dairies.

Key words: digestion analysis, methodology, lactation performance

\section{INTRODUCTION}

Dairy cattle metabolizable energy, microbial protein, and subsequent milk production models rely on predicting dietary TDN. Modeling dietary TDN first requires accurate and precise feed nutrient measurement for each diet ingredient and then requires summing nutrient concentrations and estimating apparent nutrient digestibility coefficients (Weiss et al., 1992). Determining feed nutrient concentration is common practice for commercial dairy nutritionists. However, measuring nutrient digestibilities has been challenging, for both individual ingredients and the total mixed diet. Commercial forage testing laboratories utilize various in vitro and in situ ruminal and postruminal digestion techniques to predict individual nutrient digestibilities as input for TDN models (NRC, 2001). However, commercially available methodologies vary widely and few have been related to dairy cattle performance. As a result, under most field circumstances, TDN is estimated using mechanistic approaches, such as in CNCPS v6.1 (Cornell University, Ithaca, NY), or empirical models such as that published by the NRC (2001).

In the scientific community, measuring in vivo apparent total-tract nutrient digestibility using markers is common. One of the first published accounts of a method to measure food digestion was reported in 1926 and utilized the amount of iron oxide in the food and feces as a marker (Bergeim, 1926). Kane et al. (1950) compared techniques for measuring nutrient digestibility in dairy cattle, evaluating total fecal collection 
and chromium oxide and lignin markers. The authors observed no significant difference between the methods tested in determining apparent digestibilities, but indicated that use of lignin should be adopted with caution because it is not a chemically defined entity. Lignin has been found to be partially digestible (Fahey and Jung, 1983), and poor precision in measuring lignin in commercial forage analysis laboratories limits its potential as an internal marker.

Lopes et al. (2009) successfully used in vitro indigestible NDF (iNDF) as an internal marker to estimate in vivo nutrient digestibility under controlled circumstances. Like lignin, the iNDF fraction is not chemically defined; however, the advent of improved in vitro methodology precision (Goeser et al., 2009) and the indigestibility by nature of analysis may be an advantage over lignin as a marker.

To our knowledge, measuring in vivo apparent digestibilities on commercial dairies to improve TDN estimations for diet formulation or for troubleshooting has not been successful. Administering and analyzing accepted external markers, such as chromium oxide or lanthanum oxide, is time- and cost-prohibitive in the field. Lignin has long been used as an internal marker; however, complete recovery and quantification are difficult, among other issues (Fahey and Jung, 1983). As a result, the lignin ratio technique has not been adopted in the field.

Our objective was to determine if apparent total-tract nutrient digestibilities, measured with practical methodology and using 120-h iNDF as an internal marker, were related to dairy cattle production parameters.

\section{MATERIALS AND METHODS}

From August 2010 to July 2011, TMR and fecal samples were collected from 39 commercial Midwest dairies. The dairies were located in Indiana, Michigan, Minnesota, and Wisconsin. Midwestern US diets are generally approximately $50 \%$ forage, and the forages are mostly alfalfa and corn silage. Soybean and canola meals and corn byproducts make up most diet protein.

Two sample sets were taken from each dairy, separated in time by at least $3 \mathrm{wk}$ and targeted to be taken within $7 \mathrm{~d}$ of herd DHIA testing. Sampling protocols were designed to be simple and fit within the time constraints of field nutritionists. Total mixed ration and fecal samples were collected from 1 pen per dairy in each dairy's high-production pen. The TMR samples were targeted to be taken within $2 \mathrm{~h}$ of feed delivery. Five samples, each weighing approximately $500 \mathrm{~g}$, were taken using a hand-scoop technique from evenly spaced spots throughout the length of the feed bunk. Samples were combined in a pail and mixed, and then the pail was turned upside down to empty the entire sample onto a clean surface. The sample was then split into 4 subsamples and diagonal subsamples were discarded. The entire remaining sample was put back into the pail and mixed, and the process was repeated until the sample size was approximately $500 \mathrm{~g}$. The entire subsample was packaged in a polyethylene, self-sealing bag and labeled before shipping.

At least 10 fecal samples, each approximately 250 $\mathrm{mL}$ in volume and weighing approximately $250 \mathrm{~g}$, were taken from random, undisturbed manure piles in highproducing pens using generic measuring cups. To avoid contamination, the surface manure was pushed away from the pile before taking samples when sand or other material was noticeable. Samples were combined in a pail and mixed, and approximately 1,000 g was put into a polyethylene screw-top container. Fecal and TMR samples were either immediately shipped to Rock River Laboratory (Watertown, WI) or frozen and sent later for analysis.

The TMR and fecal samples were analyzed at Rock River Laboratory (Watertown, WI). The entire TMR and fecal samples were placed in aluminum trays, weighed wet, and then dried in a forced air oven at $55^{\circ} \mathrm{C}$ for $48 \mathrm{~h}$. Dry sample weight corrected for crucible weight was divided by wet sample weight to determine DM. Samples were ground to pass a 1-mm Udy Cyclone screen (Udy Corp., Fort Collins, CO). Samples were analyzed by AOAC (2005) for CP (method 990.03), ether extract (EE; method 920.39), and ash (method 942.05). Organic matter was calculated as 100 - ash content.

Neutral detergent fiber was determined using a modified Goering and Van Soest (1970) technique. Approximately $0.5-\mathrm{g}$ samples were weighed into a volumetric flask, and $50 \mathrm{~mL}$ of neutral detergent solution and 0.5 $\mathrm{g}$ of sodium sulfite were added. Samples were heated to $100^{\circ} \mathrm{C}$ for $5 \mathrm{~min}$ before $2 \mathrm{~mL}$ of amylase solution was added. The sample and solution were then boiled for an additional $55 \mathrm{~min}$. After $1 \mathrm{~h}$, flasks were filled half full with hot water, $2 \mathrm{~mL}$ of amylase solution was added, and the flask was swirled while policing to avoid particles clinging on the side. The solution was emptied and filtered through glass fiber paper $(3.1-\mu \mathrm{m}$ pore size, Ahlstrom Corp. 141, Ahlstrom Corp., Helsinki, Finland) and rinsed twice more with boiling water. The sample was then rinsed twice with $30 \mathrm{~mL}$ of acetone, allowing for a 2-min soak with each rinse. Samples and crucibles with glass filter paper were dried at $115^{\circ} \mathrm{C}$ for $1 \mathrm{~h}$ and weighed hot. Then, NDF (\% of DM) was calculated:

$$
\begin{gathered}
\mathrm{NDF}(\% \text { of DM })=(\text { dry NDF residue weight }) / \\
\text { (initial dry sample weight). }
\end{gathered}
$$


Starch was determined by weighing between 0.18 and $0.22 \mathrm{~g}$ of sample into a $100-\mathrm{mL}$ volumetric flask and 25 $\mathrm{mL}$ of acetate buffer was added. Sample solution was mixed and heated to $193^{\circ} \mathrm{C}$ until boiling and then the temperature was reduced to $165^{\circ} \mathrm{C}$ for $1 \mathrm{~h}$. Flasks were then removed and allowed to cool for at least $20 \mathrm{~min}$ before adding $10 \mathrm{~mL}$ of amyloglucosidase $(2 \mathrm{~mL}$ of heatstable $\alpha$-amylase brought to $100-\mathrm{mL}$ volume). Flasks were placed in a water bath set to $40^{\circ} \mathrm{C}$ for $1 \mathrm{~h}$ and then $5 \mathrm{~mL}$ of $\mathrm{ZnSO}_{4}(20 \mathrm{~g}$ of zinc sulfate brought to $200-\mathrm{mL}$ volume) and $2.5 \mathrm{~mL}$ of $\mathrm{NaOH}$ ( $4 \mathrm{~g}$ of sodium hydroxide brought up to $200-\mathrm{mL}$ volume) solutions were added. Deionized water was added to bring the final volume to $100 \mathrm{~mL}$; flasks were sealed, shaken 25 times by inversion, and poured into 100-mL glass tubes. Samples were analyzed for D-glucose concentration $(\mathrm{g} / \mathrm{L})$ using a YSI 2700 Select instrument (YSI Inc., Yellow Springs, $\mathrm{OH})$. Starch content was calculated using the following equation:

$$
\begin{gathered}
\text { Starch }(\% \text { of } \mathrm{DM})=(\text { YSI reading } \times 0.09 / \\
\text { sample weight }) \times 100 .
\end{gathered}
$$

The in vivo apparent total-tract digestibility method described by Lopes et al. (2009) was modified for routine field application. Indigestible 120-h iNDF (\% of $\mathrm{DM}$ ) was measured on TMR and fecal samples and used as an internal marker to calculate apparent nutrient digestibilities. Sample iNDF was determined using the Combs-Goeser in vitro method described by Goeser et al. (2009). Apparent total-tract nutrient digestibilities were calculated using the following equation:

Apparent nutrient digestibility $(\%)=100$

$-\{100 \times($ TMR iNDF $/$ fecal iNDF $) \times[$ fecal nutrient

content $(\%$ of DM)/TMR nutrient content

$$
(\% \text { of } \mathrm{DM})]\} \text {. }
$$

Subject herds were required to have computerized records and enroll in monthly DHI (Verona, WI) milk testing. Milk weights and fat and protein concentrations were measured by DHI-approved personnel, and electronic records were analyzed using DairyComp305 (Valley Agricultural Software, Tulare, CA) or PC Dart (Dairy Record Management Systems, Raleigh, NC). Individual cow records were averaged for pen production corresponding to manure and fecal samples for each dairy.

The experimental units (farm) were arranged in a completely randomized design. Data points were considered outliers if they were greater than 2 times the standard deviation of the mean. The laboratory reana- lyzed outliers. Data were analyzed using mixed models techniques with SAS version 9.1.3 (SAS Institute Inc., Cary, NC). The values reported by DHIA were averaged by pen corresponding to the TMR and fecal samples. Energy-corrected milk was calculated as follows:

$$
\begin{gathered}
\mathrm{ECM}=0.327 \times \mathrm{kg} \text { of milk }+12.95 \times \mathrm{kg} \text { of fat } \\
+7.2 \times \mathrm{kg} \text { of protein } .
\end{gathered}
$$

Milk yield ( $\mathrm{kg})$, ECM yield $(\mathrm{kg})$, fat (\%), protein $(\%)$, fat yield $(\mathrm{kg})$, and protein yield $(\mathrm{kg})$ were modeled as response variables. Diet DMI $(\mathrm{kg})$ obtained from reported diet formulations, TMR nutrients (\% of $\mathrm{DM})$, fecal nutrients (\% of DM), and TMR nutrient digestibilities (\%) were modeled as explanatory variables. Interactions between explanatory variables were evaluated; however, none was significant. Because fecal nutrient contents were used to calculate nutrient digestibility measures, either nutrient content or digestibility was included in the mixed models regression analysis when significant. Dairy was modeled as a random effect and 2 models were compared: (1) a more complex model described by St. Pierre (2011) that allowed for different intercepts, and (2) a simple model with a single intercept. The simpler model was chosen in each case based on similar Akaike and Bayesian information criteria between the models.

We used forward selection to determine the final models. The final model for milk yield, ECM yield, and fat yield was

$$
\mathrm{Y}_{\mathrm{ijkl}}=\mu+\mathrm{D}_{\mathrm{i}}+\mathrm{O}_{\mathrm{j}}+\mathrm{C}_{\mathrm{k}}+\mathrm{F}_{\mathrm{l}}+\mathrm{e}_{\mathrm{ijkl}} \text {, }
$$

where $\mathrm{Y}_{\mathrm{ijkl}}=$ the dependent variable ( $\mathrm{kg}$ of milk, ECM, or fat yield), $\mu=$ population mean, $\mathrm{D}_{\mathrm{i}}=$ fixed effect of DMI i, $\mathrm{O}_{j}=$ fixed effect of OM digestibility $\mathrm{j}, \mathrm{C}_{\mathrm{k}}=$ fixed effect of fecal CP (\%) k, $\mathrm{F}_{1}$ = fixed effect of fecal $\mathrm{EE}(\%) \mathrm{l}$, and $\mathrm{e}_{\mathrm{ijkl}}=$ random residual error, assumed to be normally distributed. The final model for milk protein content (\%) was

$$
\mathrm{Y}_{\mathrm{ij}}=\mu+\mathrm{P}_{\mathrm{i}}+\mathrm{e}_{\mathrm{i}}
$$

where $\mathrm{Y}_{\mathrm{ij}}=$ milk protein percentage and $\mathrm{P}_{\mathrm{i}}=$ fixed effect of CP digestibility (\%) i. The final model for protein yield was

$$
\mathrm{Y}_{\mathrm{ijkl}}=\mu+\mathrm{D}_{\mathrm{i}}+\mathrm{O}_{\mathrm{j}}+\mathrm{P}_{\mathrm{k}}+\mathrm{X}_{\mathrm{l}}+\mathrm{e}_{\mathrm{ijkl}} \text {, }
$$

where $\mathrm{Y}_{\mathrm{ijkl}}=$ milk protein yield, $\mathrm{P}_{\mathrm{k}}=$ fixed effect of $\mathrm{CP}$ digestibility (\%) $\mathrm{k}$, and $\mathrm{X}_{1}=$ fixed effect of ether extract digestibility (\%) l. Significance was declared at $P<0.05$ and tendencies at $P<0.10$. 


\section{RESULTS AND DISCUSSION}

Mean diet DMI and nutrient concentrations and descriptive statistics are reported in Table 1 . Dry matter intake ranged from approximately 22 to almost $30 \mathrm{~kg} /$ cow per day, consistent with high-producing cows. The carbohydrate fractions NDF and starch ranged from approximately 27 to $44 \%$ and from 22 to $36 \%$ of DM, respectively. Crude protein and $\mathrm{EE}(\%$ of $\mathrm{DM})$ ranged from approximately 13 to $20 \%$ and from 1.5 to $5.3 \%$ of DM, respectively. Collectively the descriptive statistics for nutrient concentrations suggest that a broad variety of diets were sampled in this study.

Milk yield and component concentrations and yield means and descriptive statistics are reported in Table 1. Mean ECM yield was $43 \mathrm{~kg}$, with a range of approximately 30 to $60 \mathrm{~kg}$. Milk yield (kg) averages showed a similar range. Mean yields are consistent with high-producing cow pens across Midwestern commercial dairies.

Mean in vivo nutrient digestibility and descriptive statistics are reported in Table 1. Apparent OM digestibility averaged $63 \%$ and ranged from approximately 44 to $85 \%$. Adjusted regression parameter estimates for apparent digestibility and production components are presented in Table 2. Organic matter digestibility was significantly related to milk, ECM, fat, and protein yields (kg). Milk and ECM were also significantly relat- ed to DMI, fecal CP, and fecal EE percentages. Simple ECM plots against both DMI (kg/cow per day) and OM digestibility (\%) along with unadjusted regression lines and $\mathrm{R}^{2}$ values are presented in Figures $1 \mathrm{a}$ and $1 \mathrm{~b}$, respectively, to visually present the data and variation.

Although DMI and apparent nutrient digestibilities have been related to production under controlled research experiments (NRC, 2001), no studies, to our knowledge, have related commercial OM digestibility measure to milk production for commercial Midwestern US herds. Previous unreported attempts to measure commercial diet digestibility may have used lignin as an internal marker but likely failed because of the limitations mentioned previously.

The positive relationship between diet OM digestibility and milk production (Table 2 ) is likely related to increased diet energy available for maintenance, pregnancy, and milk production (NRC, 2001). Decreased fat digestion and FA absorption, causing more FA to pass through the cow and higher fecal EE content, yielding less energy for milk production, could explain the negative association between fecal $\mathrm{EE}$ and milk production.

The positive relationship of fecal $\mathrm{CP}$ with milk yield (Table 2) may be related to increased OM digestibility and increased microbial biomass. Undigested feed N, microbial CP (MCP) production (ruminal or postruminal), and sloughed animal tissue affect fecal

Table 1. Diet formulated and measured nutrients, calculated in vivo apparent digestibility coefficients, and production descriptive statistics for high-producing cows on 39 commercial Midwestern US dairies

\begin{tabular}{|c|c|c|c|c|}
\hline Item & Mean & Minimum & Maximum & SD \\
\hline \multicolumn{5}{|c|}{ Formulated diet nutrients, $\%$ of DM } \\
\hline Forage & 52.0 & 36.8 & 70.8 & 5.9 \\
\hline Forage NDF & 20.9 & 15.0 & 27.0 & 2.4 \\
\hline $\mathrm{OM}$ & 93.8 & 91.2 & 95.8 & 1.0 \\
\hline NDF & 30.3 & 23.7 & 37.2 & 2.9 \\
\hline Starch & 25.6 & 19.4 & 32.1 & 2.8 \\
\hline $\mathrm{CP}$ & 17.1 & 16.2 & 18.5 & 0.5 \\
\hline Ether extract & 4.3 & 2.8 & 5.6 & 0.6 \\
\hline \multicolumn{5}{|c|}{ Measured diet nutrients, \% of DM } \\
\hline $\mathrm{OM}$ & 92.1 & 86.5 & 93.8 & 1.0 \\
\hline NDF & 33.4 & 26.9 & 43.9 & 3.9 \\
\hline Starch & 28.8 & 22.0 & 36.2 & 3.2 \\
\hline $\mathrm{CP}$ & 16.8 & 13.2 & 20.0 & 1.4 \\
\hline Ether extract & 3.67 & 1.47 & 5.30 & 0.7 \\
\hline \multicolumn{5}{|c|}{$\begin{array}{l}\text { Calculated in vivo digestibility } \\
\text { coefficients. } \%\end{array}$} \\
\hline $\mathrm{OM}$ & 63.0 & 43.9 & 85.5 & 6.9 \\
\hline NDF & 35.7 & 14.8 & 69.0 & 10.8 \\
\hline Starch & 89.6 & 72.4 & 95.2 & 4.5 \\
\hline $\mathrm{CP}$ & 60.1 & 31.9 & 84.3 & 8.3 \\
\hline Ether extract & 81.5 & 44.2 & 95.2 & 8.4 \\
\hline \multicolumn{5}{|c|}{ Production measures } \\
\hline DMI, kg & 25.8 & 22.7 & 29.5 & 1.8 \\
\hline Fat, $\%$ & 3.54 & 2.90 & 4.20 & 0.30 \\
\hline Protein, \% & 3.03 & 2.70 & 3.30 & 0.17 \\
\hline Fat yield, $\mathrm{kg}$ & 1.53 & 1.04 & 2.32 & 0.25 \\
\hline Protein yield, $\mathrm{kg}$ & 1.31 & 0.93 & 1.70 & 0.17 \\
\hline $\mathrm{ECM}, \mathrm{kg}$ & 43.3 & 29.7 & 60.1 & 6.1 \\
\hline
\end{tabular}


Table 2. Regression explanatory variable parameter estimates (SE in parentheses) related to dairy production parameters

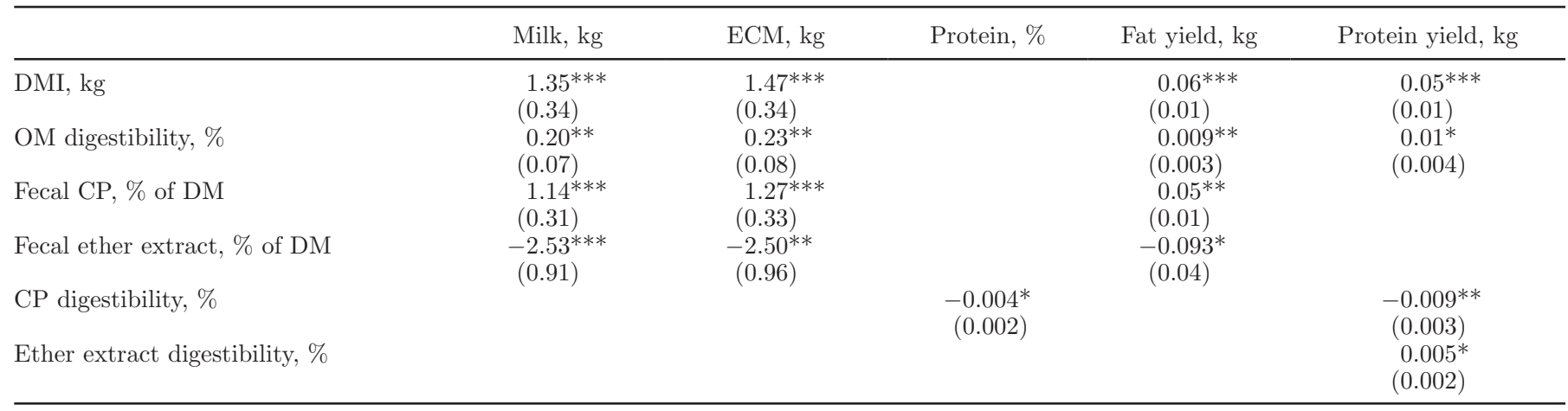

$* P<0.05 ;{ }^{* *} P<0.01 ;{ }^{* * *} P<0.001$.

CP content. Increased microbial biomass production, either ruminal or postruminal, could cause increased $\mathrm{CP}$ passage into feces. We speculate that the positive relationship between fecal CP concentration and milk yield is a byproduct of increased diet energy available for both milk production and MCP production. Alternatively, if the increased fecal CP were caused by poor diet CP digestibility, we would not expect greater milk production.

Milk protein percentage was negatively related to apparent $\mathrm{CP}$ digestibility (Table 2), which agrees with the previous discussion. Increased MCP production could be associated with greater milk protein percentage, and greater MCP can cause decreased apparent CP digestibility. Milk protein yield was related to DMI, apparent $\mathrm{OM}, \mathrm{CP}$, and EE digestibilities (Table 2). The factors influencing protein yield may be a combination of those influencing milk yield (DMI, OM digestibility, and fecal $\mathrm{EE}$ ) and milk protein percentage (apparent $\mathrm{CP}$ digestibility).

Milk fat concentration was not related to any parameters measured. However, fat yield was related to DMI, apparent OM digestibility, fecal EE concentration, and fecal CP concentration (Table 2). These same factors were related to milk and ECM production. Because the milk fat concentration was not influenced, fat yield was likely related to increased milk yield.

Diet NDF and starch concentrations and their respective digestibilities were not related to production parameters in this study. These observations contrast with many years of controlled research that documents clear relationships between apparent carbohydrate digestibility and production. However, the lack of relationship may be explained by the constantly changing nature of dairy diets and the approaches that field nutritionists use in formulating diets to overcome poor NDF or starch digestion and maintain diet energy and production in commercial dairies. As an example, if diet NDF digestibility and production is poor, the nutritionist may respond by decreasing diet NDF and increasing starch or fat to increase diet energy concentration available for milk production. In this situation, by minimizing the kilograms of digested NDF in that diet, production could be increased; however, diet NDF digestibility could still be poor. A similar argument could be used for starch. Effects of diet carbohydrate concentrations and digestibility on commercial dairy performance warrant further evaluation.

Digestible OM intake was calculated as DMI multiplied by apparent OM digestibility. Energy-corrected milk was then plotted against digestible OM intake to present a simple visual evaluation of the combined effects of OM digestibility and DMI upon ECM (Figure $1 c)$. The plot resulted in an unadjusted $R^{2}$ value of 0.21 , suggesting that, for commercial dairies, digestible OM intake may explain somewhere close to $20 \%$ of the variation in milk production. Figure 1c acknowledges the fact that although DMI and OM digestibility are highly significant in relation to ECM, the combined explanatory parameters fail to explain most variation in ECM. Sampling and analytical error, combined with many other factors such as dairy herd management, facilities, genetics, and environment likely explain the remaining $80 \%$ of variation in ECM.

The significant relationships between OM digestibility, along with $\mathrm{CP}$ and $\mathrm{EE}$ measures, and production measures, demonstrate that commercial iNDF can be accurately used to calculate apparent OM digestibility. Variation between commercial laboratories in iNDF analysis was not assessed but warrants further evaluation. The described approach for practically measuring in vivo OM digestibility offers nutritionists the ability to benchmark or troubleshoot diet performance. In troubleshooting situations, nutritionists can compare nutrient digestibility coefficients to the means described in Table 1 as an initial benchmark. Sample OM digestibility can be evaluated, followed by NDF and starch digestibility coefficients if OM digestibility suggests 
a)

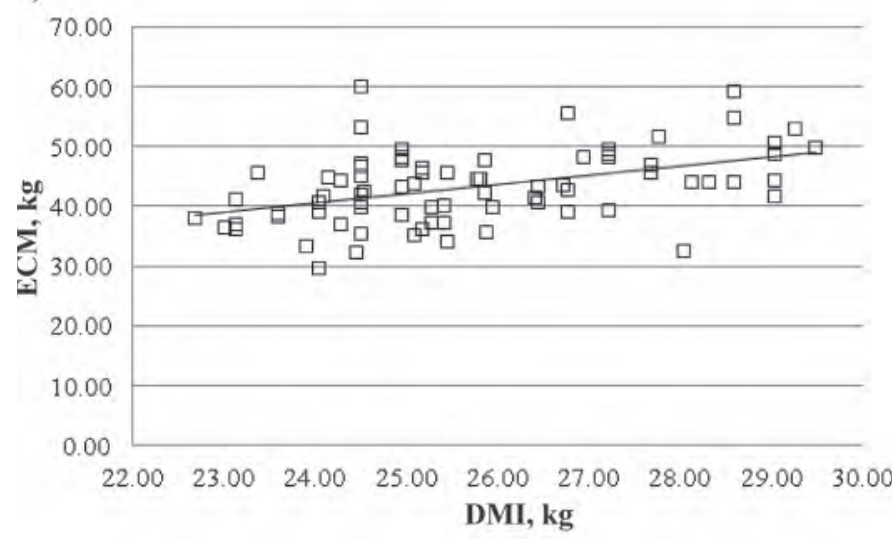

b)

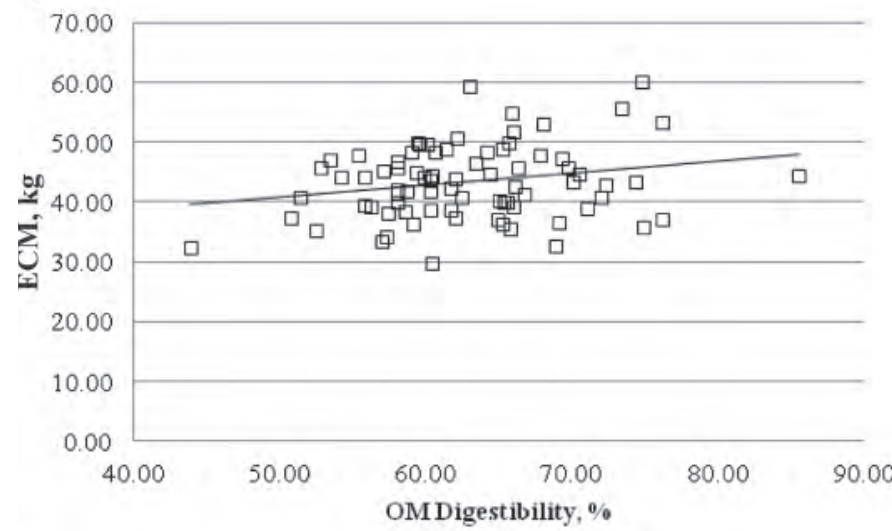

c)

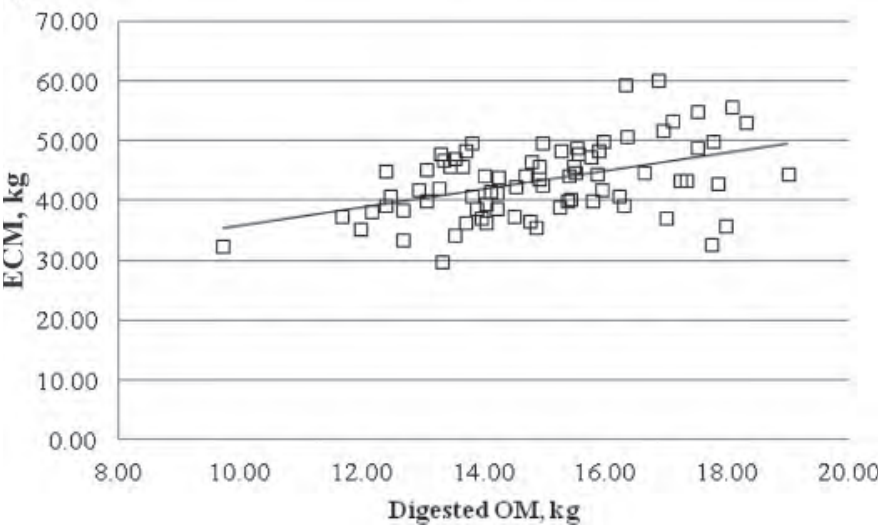

Figure 1. (a) Plot of diet DMI and ECM (unadjusted $\mathrm{R}^{2}=0.21$ ); (b) plot of diet OM digestibility and ECM (unadjusted $\mathrm{R}^{2}=0.05$ ); (c) plot of digested OM and ECM (unadjusted $R^{2}=0.21$ ) for highproducing cow pens of 39 commercial dairies.

opportunities. Although NDF and starch digestibility were not significantly related to production parameters in this study, we speculate that the coefficients may still offer insight to carbohydrate digestion. Crude protein and EE digestibilities are less straightforward due to endogenous contributions. Future digestion coefficient results could be used to update regional digestibility coefficient benchmarks.

Further, by better knowing diet OM digestibility, nutritionists may improve microbial biomass predictions in nutrition models. Controlled field-scale research and development can be further advanced using farm as an experimental unit and using the presented digestion measures at a reasonable cost. Nutrition model developers can also have confidence in the technique for collecting field data for continued model development and validation. It is our hope that this in vivo methodology can be used to accelerate dairy nutrition model development, thus allowing improved dairy cattle performance. The analysis is projected to cost approximately 5 to 10 times that of a commercial forage analysis.

\section{ACKNOWLEDGMENTS}

We acknowledge the contributions of Stacy Nichols and Eric Schwab of Vita Plus Corp. (Madison, WI) and Don Meyer of Rock River Laboratory (Watertown, WI) to this research. We also extend thanks to Bruno Amaral, Barry Visser, Ken Casebere, Kate McAndrews, Tom Berning, Andy Carlson, John Kjolhaug, Eric Schwab, Jon Rasmussen, and Bryan Knoper of Vita Plus Corp. and to Joshua Sazama, Terry Kuhn, and Matt Lamberson of Ag Partners Coop. (Redwing, $\mathrm{MN}$ ) for volunteering their time and collecting samples and data.

\section{REFERENCES}

AOAC (Association of Official Analytical Chemists). 2005. Official Methods of Analysis. 18th ed. AOAC, Washington, DC.

Bergeim, O. 1926. A method for the study of food utilization or digestibility. J. Biol. Chem. 70:29-33.

Fahey, G. C. Jr., and H. G. Jung. 1983. Lignin as a marker for digestion studies: A review. J. Anim. Sci. 57:220-225.

Goering, H. K., and P. J. Van Soest. 1970. Forage Fiber Analyses (Apparatus, Reagents, Procedures, and Some Applications). Agric. Handbook No. 379. ARS-USDA, Washington, DC.

Goeser, J. P., P. C. Hoffman, and D. K. Combs. 2009. Modification of a rumen fluid priming technique for Measuring in vitro neutral detergent fiber digestibility. J. Dairy Sci. 92:3842-3848.

Kane, E. A., W. C. Jacobson, and L. A. Moore. 1950. A comparison of techniques used in digestibility studies with dairy cattle. J. Nutr. 41:583-596.

Lopes, J. C., R. D. Shaver, P. C. Hoffman, M. S. Akins, S. J. Bertics, H. Gencoglu, and J. G. Coors. 2009. Type of corn endosperm influences nutrient digestibility in lactating dairy cows. J. Dairy Sci. 92:4541-4548.

NRC. 2001. Nutrient Requirements of Dairy Cattle. 7th rev. ed. National Academy Press, Washington, DC.

St. Pierre, N. 2011. Invited review: Integrating quantitative findings from multiple studies using mixed model methodology. J. Dairy Sci. 84:741-755.

Weiss, W. P., H. R. Conrad, and N. R. St. Pierre. 1992. A theoretically based model for predicting total digestible nutrient values of forages and concentrates. Anim. Feed Sci. Technol. 39:95-110. 